\title{
Eco-efficiency of regional development: strategical planning with DEA
}

\author{
Svetlana Ratner ${ }^{1,2, *}$, and Andrey Kovalev ${ }^{2}$ \\ ${ }^{1}$ RUDN University, Miklukho-Maklaya str.6, 117198 Moscow, Russia \\ ${ }^{2}$ V.A. Trapeznikov Institute of Control Sciences of Russian Academy of Sciences, Profsoyuznaya str., \\ 65, 117997 Moscow, Russia
}

\begin{abstract}
Despite the implementation of the national "Ecology" project, attempts to develop low-carbon energy and transport, the implementation of "garbage reform" and other measures aimed at reducing the negative impact of the economy on the environment, the eco-efficiency of production systems in Russia remains low. In this paper, we propose a new approach to solving the problems of comparative assessment of the effectiveness of regional environmental management systems (R-EMS), taking into account the structural heterogeneity of the regional economies. The developed approach includes the simultaneous solution of two DEA tasks, one of which is formulated to assess the eco-efficiency of the region's economy, and the other to assess the efficiency of spending funds aimed at protecting the environment in the region. As a result of solving two problems, the researcher receives a large amount of information that can be used in developing strategies for regional development. In particular, the information obtained can be used to develop measures to stimulate the activities of regional authorities in the field of environmental management and increase their responsibility for the effectiveness of environmental protection measures. The proposed approach was tested on the example of solving the problem of comparative assessment of the effectiveness of the R-EMSs in Russia in the period 2015-2019. However, the method developed by us is not tied to specific territories and can be used to conduct similar studies in other countries and regions.
\end{abstract}

\section{Introduction}

Nowadays most emerging economies consider economic growth, increasing competitiveness in world markets, mastering advanced production technologies, and solving social problems of the population as the main strategic goals of their development. At the same time, environmental problems, although they are recognized by the authorities and the business community, do not receive enough attention due to limited resources, especially finances. This situation is typical for Russia as well as for many other countries. Funding of environmental protection in Russia is significantly lower than, for example, in the developed countries of the European Union (Fig. 1).

\footnotetext{
*Corresponding author: ratner_sv@pfour.ru
} 


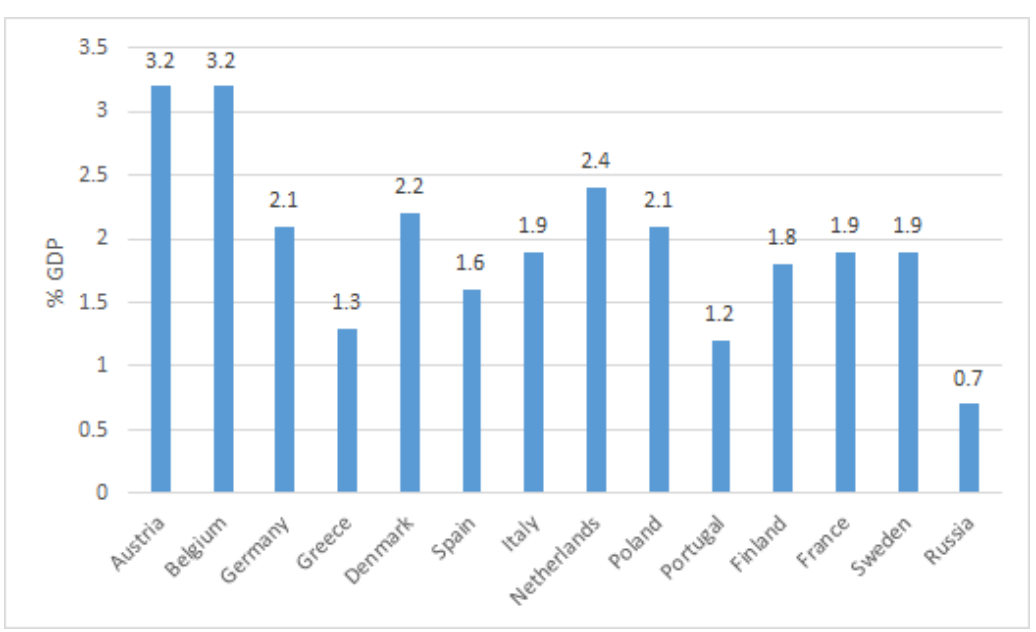

Fig. 1 Financing environmental protection (Source: authoring, based on data from Russian Federal State Statistic Service https://gks.ru/)

Despite the implementation of the national "Ecology" project, attempts to develop lowcarbon energy and transport, the implementation of "garbage reform" and other measures aimed at reducing the negative impact of the economy on the environment, the eco-efficiency of production systems in Russia remains low. This statement can be easily confirmed by cross-country comparisons of statistical indicators of resource intensity, energy intensity and carbon intensity of the Russian economy.

The main environmental problems are solved in Russia at the federal level through the implementation of federal programs and projects. At the same time, everyday monitoring of compliance with environmental legislation, collection of data on the state of the environment, educational work with the population and business, distribution of funds received in the form of payments for the negative impact of enterprises on the environment, occur at the regional level. Therefore, in the scientific literature devoted to the problems of environmental management in Russia, it is customary to talk about territorial/regional environmental management systems, although this term is not officially used either in the standards for environmental management systems of the ISO 14000 series, or in legislation. The center of decision making and the center of responsibility in the regional environmental management system is the regional ministry of natural resources and ecology (a subdivision of the regional administration). However, so far the indicators of the eco-efficiency of the regional economy are not included in the system of indicators, according to which the activities of the regional authorities are assessed (for example, the KPI indicators of the heads of the regions). In our opinion, the introduction of such indicators into the system for assessing the effectiveness of regional administrations could significantly improve the quality of environmental management at the regional level.

It should be noted that there are no generally accepted approaches to assessing the effectiveness of regional environmental management systems in the Russian literature. In studies [1-2] authors propose an approach to assess the effectiveness of a regional environmental management system based on Data Envelopment Analysis (DEA) models, in which the costs of environmental protection in the region were considered as inputs, and positive changes in the eco-efficiency of the regional economy were considered as outputs. The advantage of this approach is the comprehensive accounting of a wide range of different categories of economic impact on the environment, as well as the calculation of target indicators for each region, the achievement of which allows it to become efficient in the ecological and economic sense. In addition, the advantage of this approach is its consistency 
and naturalness, since the effectiveness of the regional environmental management system is understood in a purely economic sense, as the ratio of the positive results obtained to the costs incurred to achieve these results.

At the same time, this approach does not take into account the degree of eco-efficiency of the economies of different regions. It is well known, that the spatial development of Russia is highly heterogeneous. The regions of Russia differ significantly among themselves not only in natural and climatic conditions, area, population, level of economic development, but also in the structures of economies. Therefore, regional environmental management systems (R-EMS), as subjects of management, are initially not in equal conditions from the point of view of how complicated the object of the management is.

The aim of this study is to expand the approach originally proposed in [1-2], and adapting it to solve the problems of assessing the comparative effectiveness of regional environmental management systems, taking into account the significant heterogeneity of regions in terms of eco-efficiency.

\section{Literature review}

Eco-efficiency is a concept often used in environmental management literature. This concept was first explained in the works [3-6], who presented eco-efficiency as the ability of a production system to simultaneously achieve positive economic and environmental effects, i.e. increase profits while simultaneously reducing the negative impact on the environment. In the studies of these authors, the concept of eco-efficiency was put in contrast to the traditional idea that increasing the environmental efficiency of the production system inevitably leads to costs and, thereby, reduces economic efficiency. Thus, eco-efficiency was seen more as a process of introducing eco-innovation. This understanding is enshrined in the documents of the World Business Council for sustainable development [7], where ecoefficiency is considered as a process of constant reduction of negative environmental impacts.

Later in the literature, eco-efficiency began to be understood more "statically". For example, in [8], eco-efficiency is understood as the efficiency of using natural resources in the production of products. In [9], the eco-efficiency of a manufacturing system is understood as its ability to produce the lowest possible amount of emissions with the best available technologies. This approach to determining eco-efficiency has become widespread due to the active use of the DEA methodology in solving the problems of assessing the comparative efficiency of production systems, including regional production systems. For example, in [10-12] environmental efficiency is considered as the ability of a production system to minimize undesirable outputs (negative externalities of production activity) at fixed values of inputs (material and human resources) and desired outputs (GRP or other economic indicator of the results of the production system). In [13-14] eco-efficiency is considered to be the ability of a production system to produce the maximum desired outputs with minimum negative environmental impacts. This implies that the reduction of negative environmental effects is achieved through a more rational use of all types of input resources, i.e. ecoefficiency includes the efficient use of not only natural resources, but also human and financial resources. In addition, the desired output is not only the GRP as a useful result of the regional economy, but also the size of the population. That is, the eco-efficiency of the household sphere is taken into account (the housing and communal services of the region, the system of urban mobility, etc.). We consider this idea of eco-efficiency is the most holistic and will use it in our study.

With regard to understanding the effectiveness of the environmental management system in the region, as noted above, we rely on the approach proposed in [1-2]. In these studies, the environmental management system is considered effective if, at the lowest cost for 
environmental protection, it allows achieving the greatest positive changes in the ecoefficiency of the region.

\section{Methodology}

The inputs and outputs of the two DEA models, solved in parallel, are presented in Table 1. The choice of specific statistical indicators for assessing the impact of the regional economy on the environment is due to the peculiarities of statistical accounting of the state of the environment in the Russian Federation. We took into account all the indicators published in the public domain on a regular basis.

The first problem is the problem of determining the comparative eco-efficiency of the region and can be solved both for one period (as a rule, one year), and for a time interval (for example, for 3 - 5 years). In the second case, the given problem is dynamic, and to solve it we can use the "window" method or other methods for solving dynamic problems. We solve Problem 1 over a period of 5 years (from 2015 to 2019) and use the "window" method. As shown in [13], this time period is optimal for solving dynamic problems of assessing the comparative effectiveness of the development of regional economic systems, since it fully fits into the time frame of cardinal technological changes.

Table 1. Inputs and outputs of DEA models

\begin{tabular}{|c|c|c|}
\hline Problem & Inputs & Outputs \\
\hline $\begin{array}{l}\text { 1. Determination } \\
\text { of the comparative } \\
\text { eco-efficiency of } \\
\text { the region }\end{array}$ & $\begin{array}{l}\text { 1. Air emissions from stationary } \\
\text { sources (thousand tons); } \\
\text { 2. Air emissions from mobile sources } \\
\text { (thousand tons); } \\
\text { 3. Wastewaters (million cubic meters); } \\
\text { 4. Fresh water use (million cubic } \\
\text { meters); } \\
\text { 5. Wastes (tons) }\end{array}$ & $\begin{array}{l}\text { 1. GRP (million rubles); } \\
\text { 2. Population. }\end{array}$ \\
\hline \multirow{4}{*}{$\begin{array}{l}\text { 2. Determination } \\
\text { of the comparative } \\
\text { effectiveness of } \\
\text { the regional } \\
\text { environmental } \\
\text { management } \\
\text { system }\end{array}$} & \multicolumn{2}{|c|}{ In the field of economy } \\
\hline & $\begin{array}{l}\text { 1. Current } \begin{array}{c}\text { expenses } \\
\text { environmental protection } \\
\text { (million }\end{array} \\
\text { rubles); } \\
2 . \quad \text { Investments in fixed assets aimed } \\
\text { at environmental protection (million } \\
\text { rubles) }\end{array}$ & $\begin{array}{l}\text { 1. Change in specific emissions into the } \\
\text { atmosphere from stationary sources (thousand } \\
\text { tons / million rubles); } \\
\text { 2. Change in specific emissions into the } \\
\text { atmosphere from mobile sources (thousand } \\
\text { tons / million rubles); } \\
\text { 3. Change in the specific collection of } \\
\text { wastewater (million cubic meters / million } \\
\text { rubles) } \\
\text { 4. Change in specific consumption of fresh } \\
\text { water (million cubic meters / million rubles); } \\
\text { 5. Change in specific waste generation (tons } \\
\text { / million rubles) }\end{array}$ \\
\hline & \multicolumn{2}{|c|}{$\begin{array}{l}\text { In the field of housing and communal services } \\
\text { and personal mobility }\end{array}$} \\
\hline & $\begin{array}{l}\text { 1. Current } \begin{array}{c}\text { expenses } \\
\text { protection }\end{array} \text { for } \\
\text { (million } \\
\text { rubles); } \\
2 . \quad \text { Investments in fixed assets aimed } \\
\text { at environmental protection (million } \\
\text { rubles) }\end{array}$ & $\begin{array}{l}\text { 1. Change in specific emissions into the } \\
\text { atmosphere from stationary sources (thousand } \\
\text { tons / person); } \\
\text { 2. Change in specific emissions into the } \\
\text { atmosphere from mobile sources (thousand } \\
\text { tons / person); } \\
\text { 3. Change in the specific collection of } \\
\text { wastewater (million cubic meters / person) } \\
\text { 4. Change in specific consumption of fresh } \\
\text { water (million cubic meters / person); } \\
\text { 5. Change in specific waste generation (tons } \\
\text { / person) }\end{array}$ \\
\hline
\end{tabular}


Problem 2 is also solved over a period of 5 years, but with the usual "static method". Changes in specific negative environmental effects are calculated as the difference between the specific effect at time $t 1$ (beginning of the period) and the specific effect at time $t 2$ (end of the period). The specific negative environmental effect is understood as the volume of negative impact on the environment (for example, the volume of emissions into the atmosphere) per unit of GRP (or per person). This indicator is a lot like the indicators of resource intensity (energy intensity, carbon intensity, etc.). Current costs are summed up over the entire period. Investments in fixed assets are summed up in a similar way. With this formulation of the problem, we manage to avoid the need to assess the return on investment or take into account the corresponding time lags between the investment and the receipt of a positive result from them. Note that in both problems, all indicators measured in monetary units must be deflated, i.e. take into account the change in the value of money over time, since otherwise comparisons of indicators in different periods will be inappropriate.

Another feature of our approach is the complex formulation of problem 2. This complexity lies in the fact that the task of assessing the comparative efficiency of the regional environmental management system is divided into two in accordance with two areas of regional development: economics and the residential sector. Further, the overall efficiency is calculated as the arithmetic average of the two efficiency ratios.

The mathematical formulation of the DEA problem is traditional for BCC problems [1516]. It is well known that, BCC problems are more realistic, since they take into account the basic laws of economic development, and their solution provides more information that can be used to make management decisions. [17]. In particular, this is information about the scale effect of each of the objects under study, about the ratio of the pure technical efficiency of the object and its scale efficiency, etc. In addition, BCC tasks allow you to deal with negative outputs (if any of the objects under study) by performing a scale shift procedure [18].

The solution of two DEA problems provides a large amount of information that can be used to develop a strategy for regional development (Table 2).

Table 2. Indicators obtained because of solving DEA problems

\begin{tabular}{|l|l|}
\hline Problem & Indicators \\
\hline $\begin{array}{l}\text { 1. Determination of the } \\
\text { comparative eco- } \\
\text { efficiency of the region }\end{array}$ & $\begin{array}{l}\text { 1. Eco-efficiency scores of the region for each year of the study period; } \\
\text { 2. Benchmarks (reference objects) for } \\
\text { each region for each year of the study } \\
\text { period; } \\
\text { 3. Projections (targets) of inputs (or outputs) that a region needs to } \\
\text { achieve in order to become eco-efficient for each region in each year of } \\
\text { the study period; } \\
\text { 4. Direction of economies of scale (increasing, decreasing, constant) } \\
\text { for each region in each year of the study period; } \\
\text { 5. Scores of pure technical eco-efficiency and eco-efficiency by scale } \\
\text { for each region in each year of the study period; }\end{array}$ \\
\hline $\begin{array}{l}\text { 2. Determination of the } \\
\text { comparative } \\
\text { effectiveness of the } \\
\text { regional environmental } \\
\text { management system }\end{array}$ & $\begin{array}{l}\text { 2. Efficiency scores of regional RSEM for the study period; } \\
\text { study; } \\
\text { 3. Projections (targets) of inputs (or outputs) that the R-EMS needs to } \\
\text { achieve in order to become effective for each region over the period; } \\
\text { 4. Direction of economies of scale (increasing, decreasing, constant) } \\
\text { for each R-EMS for the period under study } \\
\text { 5. Scores of pure technical efficiency and efficiency by scale for each } \\
\text { R-EMS for the period. }\end{array}$ \\
\hline
\end{tabular}


The most interesting for practical applications are cases when a region with high ecoefficiency has an environmental management system with low efficiency, and vice versa, when a region with low eco-efficiency has R-EMS with high efficiency. The environmental management practices used in such regions can be considered the worst and the best, respectively, with all the ensuing administrative consequences (punishment / reward).

\section{Results and Discussion}

Our calculations showed that the regions with the highest eco-efficiency in the period from 2015 to 2019 are:

1) in the Central Federal District: Bryansk, Vladimir, Ivanovsk, Kaluga regions, and city of Moscow;

2) in the North-West Federal District: the Kaliningrad region;

3) in the Southern Federal District: Sevastopol and the Republic of Crimea;

4) in the North Caucasian Federal District: the Republic of Dagestan, Ingushetia, the Kabardino-Balkarian Republic and the Chechen Republic;

5) in the Volga Federal District: the Republic of Mordovia, the Chuvash Republic, the Saratov and Ulyanovsk regions;

6) in the Ural Federal District: Kurgan and Tyumen regions;

7) in the Siberian Federal District: Altai and Omsk regions;

8) in the Far Eastern Federal District: Sakhalin Region and Chukotka Autonomous District.

Eco-efficiency in 67 regions during 2016-2019 is growing (although not always monotonously), in 13 regions it is falling, in 2 regions it remains stable. Regions with diminishing eco-efficiency are the Oryol and Tambov regions, the Stavropol Territory, the city of Sevastopol, the Republic of Crimea, the Chuvash Republic, the Saratov Region, the Chelyabinsk Region, the Altai Territory, the Omsk and Tomsk Regions, and the Chukotka Autonomous District.

Regions with the highest efficiency of the R-EMS during 2015-2019 are:

1) in the Central Federal District: Bryansk, Ivanovskaya, Kostroma, Moscow and Tver regions;

2) in the Northwestern Federal District: the Komi Republic, Vologda, Leningrad, Murmansk, Novgorod and Pskov regions,

3) in the Southern Federal District: the Republic of Adygea, the Republic of Kalmykia and the city of Sevastopol;

4) in the North Caucasian Federal District: the Republic of Dagestan, Ingushetia, the Kabardino-Balkarian Republic, the Karachay-Cherkess Republic, the Republic of North Ossetia - Alania, the Chechen Republic;

5) in the Volga Federal District: no R-EMS with high efficiency;

6) in the Ural Federal District: Chelyabinsk Region;

7) in the Siberian Federal District: Altai Territory, Republic of Tyva, Republic of Buryatia, Transbaikal Territory;

8) in the Far Eastern Federal District: the Jewish Autonomous Region and the Chukotka Autonomous District.

Almost all regional environmental management systems have diminishing economies of scale, both in the economic sphere and in the sphere of housing and communal services and personal mobility. This means that an increase in the financing of the R-EMS (current costs and investments in fixed assets) leads to a disproportionately small increase in the ecoefficiency of the regions. The only exceptions are the R-EMS of the Bryansk Region, the Republic of Ingushetia, the Republic of Kalmykia, the Chechen Republic and the Republic of Tyva. 
The largest number of questions arise about the activities of the R-EMS of the Kursk region, Moscow city, the Kaliningrad region, the Republic of Crimea, the Republic of Mordovia, the Chuvash Republic, the Saratov region, the Kurgan region, the Altai Territory, the Omsk region and the Sakhalin region, where, with high eco-efficiency of the regions themselves, the efficiency of the RSEM is low. Based on the study, it can be concluded that in these regions funds for environmental protection are spent ineffectively, although the structure of the economy is quite favorable.

Regional environmental management systems with the most effective approaches and practices are R-EMSs of the Kostroma region, the Komi Republic, the Vologda region, the Leningrad, Murmansk and Novgorod regions, the Republic of Adygea, the Republic of Karachay-Cherkessia, the Republic of Buryatia and the Zabaikalsky region, where, with an unfavorable economic structure and the low eco-efficiency of the regions themselves, the costs of environmental protection bring significant changes in eco-efficiency.

\section{Conclusion}

In this paper, we propose a new approach to solving the problems of comparative assessment of the effectiveness of regional environmental management systems, taking into account the structural heterogeneity of the regional economies. The developed approach includes the simultaneous solution of two DEA tasks, one of which is formulated to assess the ecoefficiency of the region's economy, and the other to assess the efficiency of spending funds aimed at protecting the environment in the region. As a result of solving two problems, the researcher receives a large amount of information that can be used in developing strategies for regional development. In particular, the information obtained can be used to develop measures to stimulate the activities of regional authorities in the field of environmental management and increase their responsibility for the effectiveness of environmental protection measures. The proposed approach was tested on the example of solving the problem of comparative assessment of the effectiveness of the R-EMSs in Russia in the period 2015-2019. However, the method developed by us is not tied to specific territories and can be used to conduct similar studies in other countries and regions. In addition, the developed method is not rigidly linked to a set of statistical indicators used to assess the environmental situation in any territory. The statistical indicators used in our calculations can be replaced with others if they reflect the negative impact of the economy and the housing and utilities sector of the region on the environment.

The limitations of the proposed approach include the fact that, due to the peculiarities of constructing efficiency boundaries in the DEA methodology, objects with zero inputs will always have the highest efficiency. In real practice of environmental management, such situations are possible. They occur when there are no environmental costs in the region at all. In our practical example, this is precisely the situation that is observed in the Bryansk region, where throughout the entire study period, investments in fixed assets aimed at protecting the environment are zero. This practical case requires additional research to understand why this is happening: the region does not need this kind of investment, or the regional authorities cannot create the necessary incentive system for enterprises to make such investments. Elimination of these limitations is the subject of further research of the authors.

\section{References}

1. S. Ratner, P. Ratner, Applied Computer Science, 13(2), 48 (2017)

2. S. Ratner, M. Zaretskaya, Quality: Access to Success, 21(175), 120 (2020)

3. A. King, M. Lenox, Management Science, 48, 289 (2002) 
4. M. Porter. America's green strategy. Scientific American, 168 (1991)

5. M. Porter, C. Van der Linde, Journal of Economic Perspectives, 9, 97 (1995)

6. M. Porter, C. Van der Linde, Harvard Business Review, 120 (1995)

7. WBCSD. Eco-Efficiency: Creating More Value with Less Impact. World Business Council for Sustainable Development, Geneva. (2000)

8. S.-O. Holm, G. Englund, Ecological Economics, 68(3), 879 (2009)

9. J.-X. Chen, Y. Zhang, S. Zheng, Journal of Cleaner Production, 233, 611 (2019)

10. N. Zhang, Y. Choi, The Social Science Journal, 50 (2), 225 (2013)

11. J. Zhang, W. Zeng, H. Shi, Ecological Indicators, 71, 218 (2016)

12. J. Huang, J. Xia, Y. Yu, N. Zhang, Ecological Indicators, 85, 674 (2018)

13. S. Ratner, P. Ratner, Measuring Efficiencies of Regional Eco-Management Systems with DEA. Proceedings of 2017 IEEE 11th International Conference on Application of Information and Communication Technologies (AICT), 2, 256 (2017)

14. S. Ratner, Automation and Remote Control, 81, 1330 (2020)

15. R.D. Burnett, D.R. Hansen, Accounting, Organizations and Society, 33(6), 551 (2008)

16. R.D. Banker, A. Charnes, W.W. Cooper, Management Sciences, 30, 1078 (1984)

17. A. Emrouznejad, G. Yang, Socio-Economic Planning Sciences, 61, 4 (2018)

18. R. Lin, W. Yang, H. Huang, Computers \& Industrial Engineering, 135, 39 (2019) 